\title{
Psychropotid holothurians (Echinodermata: Holothuroidea: Elasipodida) collected at abyssal depths from around the Crozet Plateau in the Southern Indian Ocean*
}

\author{
ANTONINA ROGACHEVA ${ }^{1 \#}$, IAN A. CROSS ${ }^{2} \&$ DAVID S. M. BILLETT ${ }^{2}$ \\ ${ }^{1}$ P.P. Shirshov Institute of Oceanology, Russian Academy of Sciences, Nakhimovsky Pr., 36, Moscow, 117997, Russia. \\ ${ }^{2}$ National Oceanography Centre, Southampton, University of Southampton Waterfront Campus, European Way, Southampton SO14 \\ 3ZH, United Kingdom

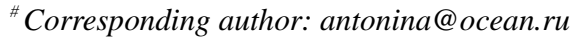

* In: Brökeland, W. \& George, K.H. (eds) (2009) Deep-sea taxonomy — a contribution to our knowledge of biodiversity. Zootaxa, 2096, 1-488.

\begin{abstract}
Seven species of holothurians of the family Psychropotidae were collected during the cruise D300 of RRS Discovery to Crozet plateau. Three of them, Benthodytes wolffi, Psycheotrephes discoveryi and Psychropotes xenochromata are described as new to science. One species, Benthodytes abyssicola Théel, regarded recently as incertae sedis, is redescribed with designation of a lectotype. Additional notes are provided to descriptions of Psychropotes scotiae (Vaney) known from two specimens and Psychropotes longicauda Théel, the cosmopolitan highly variable species.
\end{abstract}

Key words: Benthodytes, Psycheotrephes, Psychropotes, Psychropotidae, new species

\section{Introduction}

Holothurians of the family Psychropotidae are among the least studied deep-sea holothurians. The family was defined by Théel $(1879,1882,1886)$, who erected four new genera and 14 new species based on the collection of H.M.S. Challenger. Subsequently 34 species were described by Verrill (1884), von Marenzeller (1893), Ludwig (1894), Perrier (1896), Hérouard (1896, 1902), Sluiter (1901a, 1901b), Koehler and Vaney (1905), Vaney (1908), Ohshima (1915), H.L. Clark (1920) and Belyaev and Vinogradov (1969). Three of them were later transferred to other orders of holothurians. Many of remaining 31 species were synonymized by Hansen (1975), who revised the family. Hansen also regarded the genus Euphronides Théel as a synonym of the genus Psychropotes Théel and described five new species. To date the family includes three genera and 22 species. Despite Hansen's great contribution to our knowledge of the Psychropotidae, the status of many species in the family remains unclear. In particular, many problems remain with the cosmopolitan and highly variable species Psychropotes longicauda Théel and P. depressa (Théel). After Hansen's monograph only a few publications on the taxonomy of the Psychropotidae have appeared (Pawson 1985, Massin \& Sibuet 1983 and Gebruk 2008) and the family requires further study.

During the D300 cruise of RRS Discovery to Crozet Plateau in December 2005-January 2006 seven species of Psychropotidae were collected. Three of them, Benthodytes wolffi, Psycheotrephes discoveryi and Psychropotes xenochromata, are new to science. One species, Benthodytes abyssicola Théel, regarded as incertae sedis by Hansen (1975), is re-described following a re-examination of the type series. Additional notes are presented on the morphology and distribution of Psychropotes scotiae (Vaney) and P. longicauda. 


\section{Material and methods}

Psychropotid holothurians were collected around the Crozet Plateau using a semi-balloon otter trawl at six stations located in two sites under different productivity regimes (Wolff 2006; Hughes et al. 2007). One site (M5) was in a eutrophic area with high input of organic matter located in the east to north-east of the plateau. The second site (M6) was sampled under a high nutrient low chlorophyll area located to the south of the plateau (Table 1).

TABLE 1. Data on trawl stations of D300 cruise of RRS Discovery.

\begin{tabular}{llllll}
\hline Site & Station $\mathbf{~ r ~}$ & Latitude, $\mathbf{S}$ & Longitude, E & Depth, m & Date \\
\hline M5 & $15773 \# 8$ & $45^{\circ} 43.06^{\prime}$ & $56^{\circ} 32.16^{\prime}$ & $4258-4290$ & 12 Dec 2005 \\
M5 & $15773 \# 17$ & $45^{\circ} 43.47^{\prime}$ & $56^{\circ} 36.66^{\prime}$ & $4301-4283$ & 15 Dec 2005 \\
M5 & $15773 \# 23$ & $45^{\circ} 40.05^{\prime}$ & $56^{\circ} 35.27^{\prime}$ & $4269-4275$ & 16 Dec 2005 \\
M5 & $15773 \# 32$ & $45^{\circ} 40.45^{\prime}$ & $56^{\circ} 33.70^{\prime}$ & $4267-4270$ & 20 Dec 2005 \\
M6 & $15775 \# 4$ & $48^{\circ} 56.21^{\prime}$ & $51^{\circ} 03.90^{\prime}$ & $4182-4195$ & 27 Dec 2005 \\
M6 & $15775 \# 13$ & $49^{\circ} 01.15^{\prime}$ & $51^{\circ} 04.52^{\prime}$ & $4187-4191$ & 29 Dec 2005 \\
\hline
\end{tabular}

Holothurians were preserved in $4 \%$ buffered formaldehyde and later transferred to $80 \%$ ethanol. All the type specimens of the new species are stored at Natural History Museum in London (UK), other material from the D300 cruise is deposited in National Oceanography Centre in Southampton (UK).

Additional material including type material was obtained from the following museums and research centres:

National Oceanography Centre, Southampton, United Kingdom (NOC);

Natural History Museum, London, United Kingdom (NHM);

Swedish Museum of Natural History (SMNH);

Zoological Museum, Natural History Museum of Denmark, University of Copenhagen (ZMUC).

\section{Systematic Part}

Order Elasipodida Théel, 1882

Suborder Psychropotina Hansen, 1975

Family Psychropotidae Théel, 1882

Genus Benthodytes Théel, 1882

Benthodytes wolffi sp. nov. Rogacheva and Cross

(Fig. 1)

Holotype: NHM 2008.988, Specimen $9.5 \mathrm{~cm}$ long and $2.3 \mathrm{~cm}$ wide. RRS Discovery, Cruise D300, St. 15773\#17, 15 December 2005, 45 43.47'S 56 36.66'E, 4283-4301 m, semi-balloon otter trawl.

Paratypes: NHM 2008.989, 1 specimen $10.0 \mathrm{~cm}$ long and $2.7 \mathrm{~cm}$ wide; NHM 2008.990, 1 specimen 9.2 $\mathrm{cm}$ long and $2.0 \mathrm{~cm}$ wide; Cat. Nr NHM 2008.991, 1 specimen $9.0 \mathrm{~cm}$ long and $2.0 \mathrm{~cm}$ wide; NHM 2008.992, specimen $10.2 \mathrm{~cm}$ long and $2.7 \mathrm{~cm}$ wide. RRS Discovery, Cruise D300, St. 15773\#17, 15 December 2005, 45 43.47'S 56 36.66'E, 4283-4301 m, semi-balloon otter trawl.

Other material examined: RRS Discovery, Cruise D300, St. 15773\#8, 3 specimens; St. 15773\#23, 1 specimen; St. 15773\#32, 19 specimens; St. 15775\#4, 13 specimens; St. 15775\#13, 26 specimens.

Type locality: Southern Indian Ocean, north-east and south of the Crozet Islands, depth 4182-4301 m. 
Etymology. The species was named after George Wolff, the principal scientist on the RRS Discovery cruise D300 to Crozet plateau, for his research on the nutrition of deep-sea holothurians.

Diagnosis. Body elongate. Colour in alcohol light violet. Body wall thick and soft. Brim well developed with clearly visible dark violet ambulacral channels. 7 pairs of well developed dorsal papillae up to $7 \mathrm{~mm}$ in length arranged in 2 single rows, evenly distributed. 20 tentacles. Deposits absent.

Description of the holotype. Specimen $10.0 \mathrm{~cm}$ long and $2.7 \mathrm{~cm}$ wide (Fig. 1: A, B). Body convex on the dorsal side especially on the mid-dorsal interradius and more flattened on both right and left dorsal interradii. Skin partially sloughed off. Colour light violet to brownish. Brim with tips of enclosed tube feet and dark coloured ambulacral channels clearly visible. Some of 20 tentacles retracted into pockets. Midventral tube feet 23 pairs. Papillae up to $5 \mathrm{~mm}$ in length. Genital papilla clearly visible, slightly smaller than dorsal papillae.

A

A

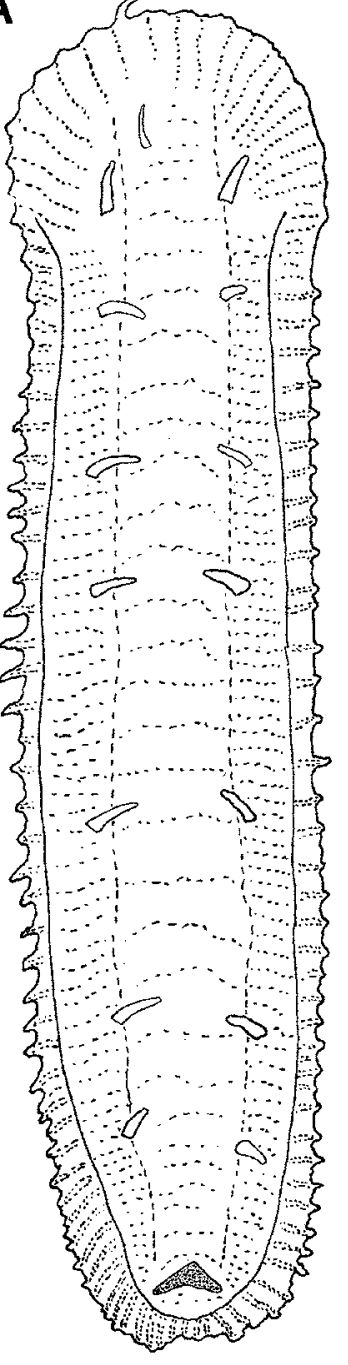

$\mathbf{B}$

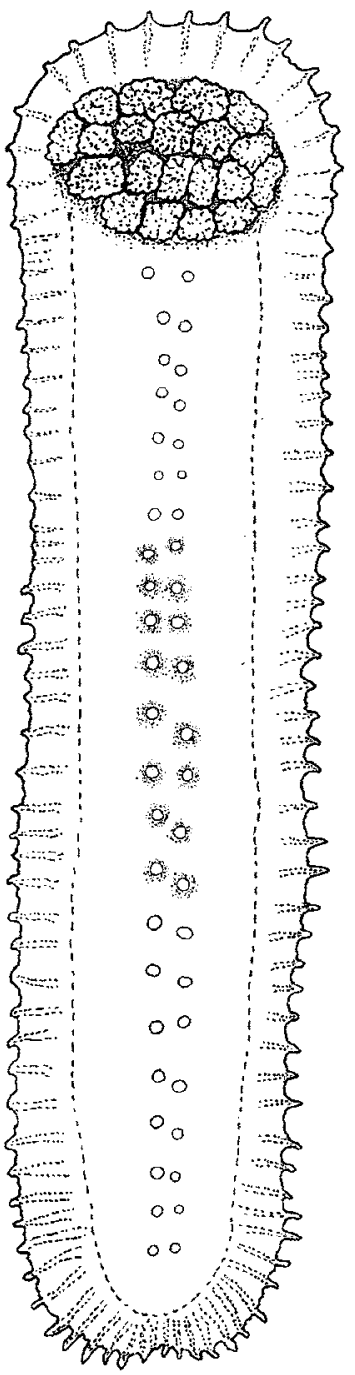

C

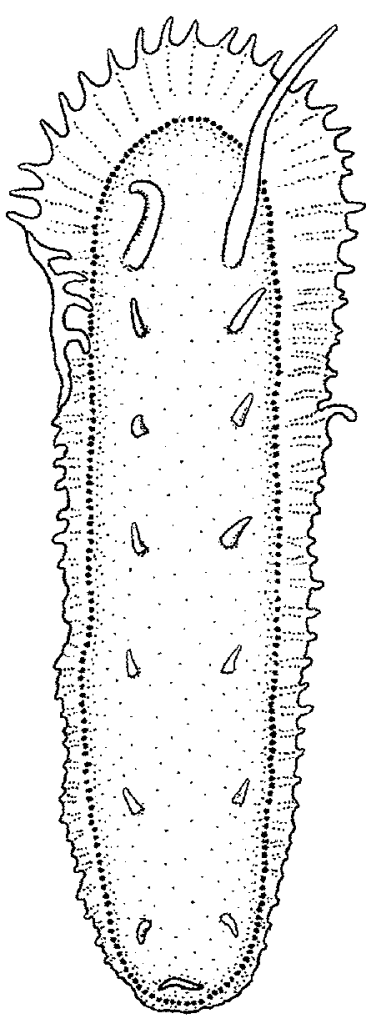

\section{$4 \mathrm{~cm}$}

FIGURE 1. Benthodytes wolffi sp. nov., holotype. A, dorsal view; B, ventral view; C, specimen from St. $15775 \# 13$.

Description. The material is damaged: most specimens lack parts of the skin, some papillae and tentacles; tentacle discs strongly deformed. Body flattened ventrally and slightly convex dorsally. The ratio 'body length: maximum width' varies from 3.7 to 4.6 in a preserved state. Body almost of the same width along the whole length, head-like part of the body slightly wider and posterior end slightly tapered. Skin thick, 
sometimes covered with warts. Colour light violet in alcohol. Brim damaged, reaching approximately $0.5 \mathrm{~cm}$; best developed around anterior and posterior parts of the body. Tentacles retracted into pockets. Circum-oral papillae visible in some paratypes. Midventral tube feet about 25 pairs, arranged in a double row, slightly randomly distributed over the mid-ventrum. In one specimen 4 pairs of additional tube feet are in the middle of the ventrum outside the midventral double row; they are darker and of the same size as tube feet within the row. 7 pairs of equally sized dorsal papillae up to $0.5 \mathrm{~cm}$ in length. 4 pairs are located on the anterior half of dorsum and the remaining 3 on the posterior half; many paratypes are incomplete and lack papillae. The fourth pair of papillae is closest to the middle of dorsum. In two specimens from St. 15775\#13 first pair of papillae is longer significantly, up to $3 \mathrm{~cm}$ in length (Fig. 1: C). Genital papilla visible in the holotype and some of the paratypes, located anteriorly from the first pair of dorsal papillae. Deposits absent in the body wall, papillae and tentacles.

Relationships. Benthodytes wolffi sp. nov. differs from other species of the genus in having seven pairs of well-developed papillae and twenty tentacles. B. wolffi is most closely related to B. typica Théel in tentacle number and the size and form of the brim.

The presence of longer papillae in two specimens from St. $15775 \# 13$ is a result of condition of preservation. B. wolffi probably has long papillae which, however, retract in most specimens during fixation.

\section{Benthodytes sanguinolenta Théel, 1882}

(Fig. 2)

Benthodytes sanguinolenta Théel, 1882: 104-105, Pls. XXIII, XL: 4-5, XLII: 6; Ludwig, 1894: 53-60, Pl. I: 1-8; Koehler and Vaney, 1905: 72; Clark, 1913: 233; Ohshima, 1915: 245; Clark, 1920: 142; Clark, 1923a: 162; 1923b: 420; Heding 1940: p. 367; Hansen, 1956: 44-45; 1975: 94-96; Pls. III-VI,IX: 6-7, XII: 4-5; Carney and Carey, 1976: 69; Pawson, 1982: 129-145; Bluhm and Gebruk, 1999: 175, Fig. 3D; Gebruk, 2008: 50,51 .

Material examined: RRS Discovery, Cruise D300, St. 15773\#8, 28 specimens; St. 15773\#17, 101 specimens; St. 15773\#23, 133 specimens; St. 15773\#32, 79 specimens; St. 15775\#4, 11 specimens; St. 15775\#13, 17 specimens.

Description of the material. Specimens varying in length from 50 to $350 \mathrm{~mm}$. Body very elongated, with a posterior taper, flattened at the anterior end (Fig. 2: A, B). The 'body length: maximum width' ratio was approximately 5.6-5.8; the body is widest at the anterior end. Brim narrow due to contraction and widest at the posterior end. Colour in alcohol ranging from dark violet to violet. Tentacles (Fig. 2: C) 18; a few specimens have 17 probably due to the loss of a tentacle. Post-oral papillae usually 17 (16-18) well developed. Midventral tube feet 47 pairs in a $20 \mathrm{~cm}$ long specimen. Dorsal papillae minute, retracted, often only dark coloured water-vascular canals can be found. Dorsal papillae arranged in 2 bands with 1-4 papillae edgewise in a band, narrowing to 1-2 papillae edgewise in a band at posterior end. Sometimes papillae present between the 2 bands. Immediately behind the gonopore, papillae are scattered irregularly, not forming bands. Deposits not found.

Remarks. Specimen morphology fits within the known range of variation of this species, described in detail by Théel (1882) and Hansen (1975).

Distribution. Benthodytes sanguinolenta is a well known cosmopolitan species. It has been found in the Atlantic (Mid-Atlantic Ridge, Peru Basin, near Bahama Islands), Pacific (Tasman Sea, Kermadec Trench, off Panama isthmus, Japan and from the Cascadia basin), Indo-Pacific region, South Africa and the Bay of Bengal. The new material from off the Crozet Islands represents the southernmost known record. Depths $768-7250 \mathrm{~m}$. 


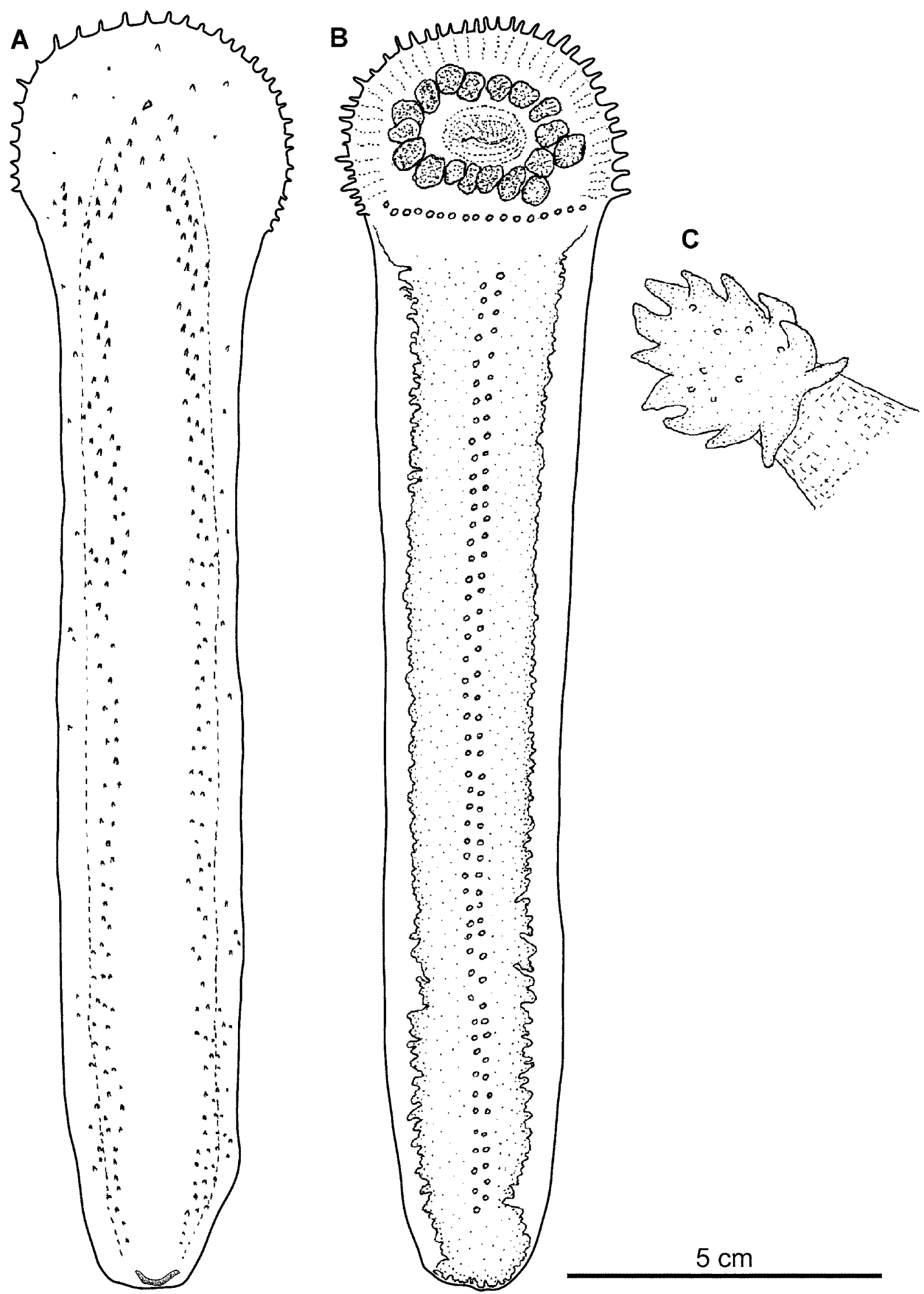

FIGURE 2. Benthodytes sanguinolenta, St. 15773\#23. A, dorsal view; B, ventral view; C, tentacle. 
Benthodytes abyssicola Théel, 1882

(Figs 3-4)

Benthodytes abyssicola Théel, 1882: 106-108, Pl. XXXVI, Fig. 26, 27; XXXVIII, Figs 1-3, XLVI, Figs 9-10.

Benthodytes abyssicola: (incertae sedis) Hansen, 1975: 76.

Benthodytes sordida Théel, 1882: 108-109, Pl. XXIV.

Benthodytes sordida: (incertae sedis) Hansen, 1975: 76.

non Benthodytes sordida: Walker et al., 1987: 277-282.

Lectotype (here designated): SMNH Type-7383 (old number 221), H.M.S. Challenger St. 298, November 17, $1875,34^{\circ} 7^{\prime} \mathrm{S} 73^{\circ} 56^{\prime} \mathrm{W}, 2225$ fathoms $(4072 \mathrm{~m})$, bottom temperature $1.3^{\circ} \mathrm{C}$, grey mud. Original label: "N 221, Benthodytes abyssicola, Lat. 34 ${ }^{\circ} 7^{\prime} \mathrm{S}$, Long. $73^{\circ} 56^{\prime} \mathrm{W}, 2225 \mathrm{fms}$, Challenger-Exp." Specimen $18 \mathrm{~cm}$ in length and $6 \mathrm{~cm}$ in maximum width.

Paralectotypes: NHM 83.6.18.73, labelled as "Benthodytes abyssicola", H.M.S. Challenger St. 298, November $17,1875,34^{\circ} 7^{\prime} \mathrm{S} 73^{\circ} 56^{\prime} \mathrm{W}, 2225$ fathoms (4072 m), bottom temperature $1.3^{\circ} \mathrm{C}$, grey mud, 3 specimens $12.5 \mathrm{~cm}, 17 \mathrm{~cm}$ and $\sim 20 \mathrm{~cm}$ long.

NHM 83.6.18.77, labelled as "Benthodytes sordida", H.M.S. Challenger St. 298, November 17, 1875, $34^{\circ} 7^{\prime} \mathrm{S} 73^{\circ} 56^{\prime} \mathrm{W}, 2225$ fathoms ( $\left.4072 \mathrm{~m}\right)$, bottom temperature $1.3^{\circ} \mathrm{C}$, grey mud, 1 specimen $22 \mathrm{~cm}$ long;

NHM 83.6.18.76, labelled as “Benthodytes sordida", H.M.S. Challenger St. 158, March 7, 1874, 50¹'S $123^{\circ} 4^{\prime} \mathrm{E}, 1800$ fathoms $(3294 \mathrm{~m})$, bottom temperature $0.3^{\circ} \mathrm{C}$, globigerina ooze, 1 specimen $20 \mathrm{~cm}$ long.

NHM 83.6.18.75, labelled as "Benthodytes sordida", H.M.S. Challenger St. 157, March 7, 1874, 53 55'S $108^{\circ} 35^{\prime} \mathrm{E}, 1950$ fathoms ( $3569 \mathrm{~m}$ ), diatom ooze, 1 specimen $23 \mathrm{~cm}$ long.

NHM 83.6.18.74, labelled as "Benthodytes sordida", H.M.S. Challenger St. 156, February 26, 1874, $62^{\circ}$ 26'S 95 44'E, 1975 fathoms (3614 m), diatom ooze, 1 specimen $20 \mathrm{~cm}$ long.

Other material examined: RRS Discovery, Cruise D300, St. 15773\#8, 8 specimens; St. 15773\#17, 33 specimens; St. 15773\#23, 68 specimens; St. 15773\#32, 29 specimens; St. 15775\#4, 18 specimens; St. 15775\#13, 3 specimens.

Diagnosis. Body elongate. Colour in alcohol dark violet. Skin gelatinous. Maximum body width at middle of body. Tentacles 15; circum oral papillae present. Brim narrow, retractile. Midventral tube feet in double row; in middle of ventrum tube feet may be arranged in single zigzag row. Dorsal papillae arranged in 2 rows: 3-4 pairs of large papillae and 1-5 pairs of minute papillae anterior to the first pair of large papillae or between larger ones; sometimes minute unpaired papillae present. Large papillae evenly distributed along dorsum: first pair located on anterior third forth of dorsum; second pair situated close to middle of dorsum, third pair on posterior third quarter or posterior one third of dorsum; fourth pair if present situated close to anus. Deposits large primary crosses with central bipartite apophyses scattered on dorsum and ventrum. Rods present in tentacles, papillae and tube feet.

Description of the lectotype. Specimen $18 \mathrm{~cm}$ in length and $6 \mathrm{~cm}$ wide at the maximum point, which lies in anterior half close to middle of body; body tapered to posterior end; body flattened ventrally, slightly convex dorsally (Fig. 4: C, D, E). Skin rather thin. Colour in alcohol brownish. Brim retracted, less than 0.5 $\mathrm{cm}$ in width. Tentacles 15 with conspicuous knobs on disc margin. Circum-oral papillae scarcely visible. Midventral tube feet about 30 pairs. Dorsal papillae 8 pairs: 3 pairs of large papillae and 5 pairs of minute ones. First pair of papillae minute, located anterior to gonopore. 3 pairs of minute papillae between first and second pairs of large papillae. No minute papillae between second and third pairs of large papillae. Large papillae increase in size towards posterior of body. Deposits not preserved.

Description of paralectotypes. NHM 83.6.18.73 (Fig. 4: F, G). Only one specimen $12.5 \mathrm{~cm}$ long is in satisfactory condition. Two others are strongly damaged and dissected. The specimen has elongate body with maximum width at mid-body. Tentacles 15. Brim narrow. Circum-oral papillae visible. 6 pairs of dorsal papillae and 4 unpaired papilla; 3 pairs of these papillae slightly larger than others; anterior pair located obliquely on first third of dorsum; other 2 pairs on middle and posterior thirds respectively. Deposits not found in body wall and tentacles. 


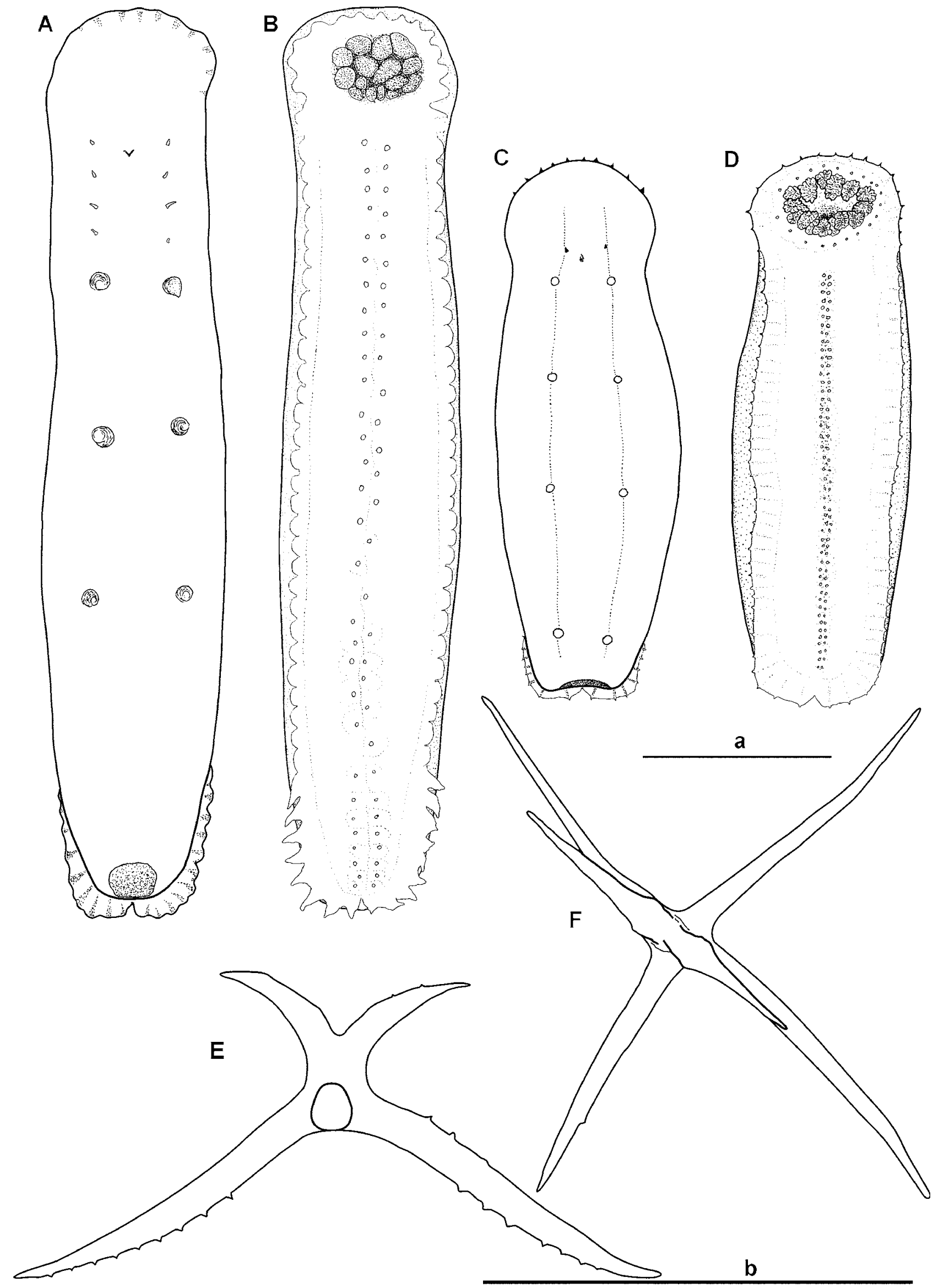

FIGURE 3. Benthodytes abyssicola. St. $15773 \# 17$ (scale a=5 cm). A, dorsal view; B, ventral view. St. $15773 \# 4$ (scale $\mathrm{a}=5 \mathrm{~cm}$ ). C, dorsal view; D, ventral view. E, F dorsal deposits (scale $\mathrm{b}=0.5 \mathrm{~mm}$ ). 



FIGURE 4. Benthodytes abyssicola. Paralectotype NHM Cat. Nr. 83.6.18.77. A, dorsal view; B, ventral view; Lectotype C, dorsal view; D, ventral view; E, tentacle disc; Paralectotype NHM Cat. Nr. 83.6.18.73. F, dorsal view; $\mathrm{G}$, ventral view. 
NHM 83.6.18.74. Specimen approximately $20 \mathrm{~cm}$ in length, strongly damaged. Colour brownish-purple. 3 pairs of minute papillae anterior to 3 pairs of large papillae and 1 pair of minute papillae between middle and posterior pairs of large papillae.

NHM 83.6.18.75. Specimen $23 \mathrm{~cm}$ in length and $8 \mathrm{~cm}$ in maximum width. Body tongue-shaped, flattened. Colour dark violet. Brim retracted, very narrow. Tentacles 15. 5 pairs of minute papillae anterior from 3 pairs of large papillae. Posteriormost pair of papillae is the largest. Deposits not found.

NHM 83.6.18.76. Specimen $20 \mathrm{~cm}$ in length; strongly deformed. Color of dorsum brownish with light violet spots; ventrum dark brown. 15 tentacles in deep pockets. Number and arrangement of both minute and large papillae are as in the paralectotype 83.6.18.77. Posteriormost pair of large papillae larger than others. Deposits not found.

NHM 83.6.18.77 (Fig. 4: A, B). Specimen $22 \mathrm{~cm}$ long, maximum width about $8 \mathrm{~cm}$ at middle of body; anterior one fourth flattened and defined by dorsal constriction. Skin thin, wrinkled, light brownish dorsally and dark brown ventrally. 3 pairs of minute papillae and 3 pairs of large papillae. Tentacles 15, 2 missing; tentacle discs flattened, with small rounded protuberances in wrinkles. Circum-oral papillae clearly visible. Brim narrow; ends of enclosed tube feet clearly visible. Midventral tube feet more than 30 pairs. Minute papillae anterior to anteriormost large pair. Right papilla of posterior pair significantly larger than left. Deposits not preserved.

Description of the Discovery D300 material. Specimens up to $25 \mathrm{~cm}$ in length, in various states of contraction. Body wall varying from relatively thin, gelatinous in some specimens to firm and leathery in others. The 'body length; maximum width' ratio varies from 3.05 in specimens $15 \mathrm{~cm}$ long to 5.3 in larger specimens, depending on state of contraction. Brim up to $12 \mathrm{~mm}$ in maximum width (at posterior end). Tentacles 15, posterior tentacles smaller than anterior. Circum-oral papillae visible in many specimens. Most specimens with 3 pairs of similarly sized large dorsal papillae located over anterior two thirds of dorsum (Fig. 3: A, B). Some specimens from St. $15775 \# 4$ possess a fourth pair of large papillae located on posterior one third of dorsum; other pairs of large papillae have same arrangement (Fig. 3: C, D). Up to 4 pairs of minute papillae in 2 rows in front of the anteriormost pair of large papillae or sometimes between them. The anteriormost pair of minute papillae usually placed slightly anterior to gonopore.

Deposits were found only in the dorsal skin around the anus in some large specimens, others entirely lacked deposits. Deposits typical of the genus Benthodytes (Fig. 3: E, F): primary crosses with a finely spinous central bipartite apophyses. Arms usually $0.40-0.45 \mathrm{~mm}$ in length (maximum $0.55 \mathrm{~mm}$ ), with small spines distributed over at least their distal half. Deposits in the tentacle stems simple rods; rods absent in some specimens. Two juvenile specimens, the first $11 \mathrm{~mm}$ long and $4 \mathrm{~mm}$ wide, and the second $19 \mathrm{~mm}$ long and 6 mm wide, from St. 15775\#13 had numerous deposits in the dorsal body wall.

Remarks. Benthodytes abyssicola and its closest relative B. sordida Théel were described from the Southern Indian Ocean and the Pacific (off Chile). According to the original description B. sordida differs from $B$. abyssicola by absence of a neck-like portion behind head-part, by a broad and thin anterior brim and by the presence of large papillae and their arrangement which is in contrast to the small dorsal papillae found in B. abyssicola. Re-examination of syntypes of B. abyssicola and B. sordida showed that all syntypes, including syntypes of $B$. abyssicola, have three pairs of large papillae and up to five pairs of minute papillae in front of the anteriormost pair of large papillae. In some syntypes of B. abyssicola these papillae are strongly retracted but still visible; large papillae are easily distinguished in the lectotype. The arrangement of papillae in the syntypes of both species is very similar. The "broad and thin brim round the head" and "narrower necklike portion immediately behind the considerably broader round and flat head-part" could only be detected in the syntype NHM 83.6.18.77. These characters very likely depend on the condition of material.

Hansen (1975) regarded this species as being of an uncertain taxonomical position because of the absence of deposits in the type material. However the presence of three (rarely four) pairs of papillae of larger size is unknown in other species. Moreover it is constant character: it was found in all examined specimens and therefore provides evidence that $B$. abyssicola is a valid species and B. sordida a junior synonym.

Specimens from around Crozet Plateau were identified as Benthodytes abyssicola based on the presence 
and arrangement of three pairs of large papillae in most, absence of a dense layer of deposits from most parts of the body wall, and the presence of a narrow brim and 15 tentacles.

Specimens from the North-East Atlantic identified by Walker et al. (1987) as Benthodytes sordida probably belong to another species. We re-examined some material representing this species from the same locality stored at NOC Southampton (Discovery collection): St. 13368\#51, 48 $50^{\prime} \mathrm{N} 16^{\circ} 28^{\prime} \mathrm{W}, 4840 \mathrm{~m}$, March 18, 1998, semi-balloon otter trawl, 1 specimen; St. 13200\#27, 4853'N 16³9'W, 4848-4839 m, July 10, 1997, semi-balloon otter trawl, 3 specimens; St. 50811, 49 $39^{\prime} \mathrm{N} 14^{\circ} 39^{\prime} \mathrm{W}, 4400-4350 \mathrm{~m}$, August 2, 1980, semiballoon otter trawl, 4 specimens; St. 13200\#9, 48 52N 16 $25 \mathrm{~W}, 4844-4840 \mathrm{~m}$, July 6, 1997, semi-balloon otter trawl, 4 specimens. Atlantic specimens are similar to B. abyssicola in presence of three pairs of large papillae as well as a few pairs of minute papillae and the 15 tentacles but differ by the absence of deposits in the thick body wall and by the shape of the body: the maximum width is in the anterior one third of the body.

Relationships. B. abyssicola differs from other species of Benthodytes in having three or four pairs of evenly distributed large dorsal papillae, with minute dorsal papillae also present. In morphology this species is most closely related to Benthodytes from the North-East Atlantic that is apparently a new species.

Distribution. Southern Indian Ocean, Pacific Ocean (off Chile). Depths 3294-4301 m.

Genus Psycheotrephes Théel, 1882

Psycheotrephes discoveryi sp. nov. Rogacheva and Cross (Fig. 5)

Psycheotrephes magna Hansen, 1975 (partim.): 97-99, figs. 37-37, Pl. XII:6.

Holotype: NHM 2008.984. Specimen $28 \mathrm{~cm}$ long and $4.5 \mathrm{~cm}$ in width. RRS Discovery, Cruise 300, St. 15773\#23, 16 December 2005, 4540.05S 56 35.27E, 4269-4275 m.

Paratypes: NHM 2008.985. 1 specimen $19 \mathrm{~cm}$ long and $6.5 \mathrm{~cm}$ wide. Fragments from $3.9 \mathrm{~cm}$ to $28.3 \mathrm{~cm}$ in length. RRS Discovery, Cruise D300, St. 15773\#23, 16 December 2005, 45 40.05S 56 35.27E, 4269-4275 m; NHM 2008.986-987. Fragments of 2 specimens. RRS Discovery, Cruise D300, St. 15773\#23, 16 December $2005,45^{\circ} 40.05 \mathrm{~S} 56^{\circ} 35.27 \mathrm{E}, 4269-4275 \mathrm{~m}$.

Type locality: Southern Indian Ocean, to north-east and to south of the Crozet Isles, depth 4182-4301 m.

Diagnosis. Body dark violet, elongate, dorsum slightly convex, ventrum flattened. Brim narrow. Tentacles 18. 3 pairs of minute papillae on anterior half of dorsum. Deposits small crosses with short, smooth central apophysis. Arms up to $0.1 \mathrm{~mm}$ long with 1 or 2 spines of same size as central apophysis or slightly smaller. Arms bent downwards.

Description of material. Specimens have suffered extensive damage; the following description represents a synthesis of characters derived from specimens and fragments. Body elongate, length from $3.9 \mathrm{~cm}$ to 28.3 $\mathrm{cm}$. Colour dark violet. Skin soft and relatively thin. 'Body length: maximum width' ratio 6.2 (it was possible to measure this ratio only in one specimen $28.3 \mathrm{~cm}$ long). Brim up to $1.7 \mathrm{~cm}$ wide in the largest specimen with prominent tips of tube feet; brim visible only from ventral side. Tentacles: 18; tentacle discs with numerous marginal knobs. Midventral tube feet arranged in double row, small and retractile. 3 pairs of minute papillae are located on anterior part of dorsum; the posteriormost pair slightly larger. Deposits (Fig. 5: A-G) small corroded crosses with arms $0.05-0.1 \mathrm{~mm}$ and central pointed apophysis; arms curved downwards, their distal part not bent upwards; arms possess 2 or rarely 1 large spine of the same size as central apophysis or slightly smaller. Arms sometimes posessing very small spines on the distal parts. Tripartite deposits occasionally present in dorsal skin. Deposits not observed in ventrum.

Remarks. The genus Psycheotrephes includes four species, two of which, $P$. exigua Théel and $P$. recta (Vaney), are known only from single records. The species P. magna was described by Hansen (1975) on material from two localities: off Madagascar-Mombasa (Galathea St. 234) and Kermadec Trench (Galathea St. 663). The holotype was designated from the Station 234. Re-examination of the type material in ZMUC 
revealed significant differences in deposit morphology in specimens from different stations. Specimens from the Station 234 have deposits with numerous spines that possess additional spines, spines often branched and arms curved upwards or horizontally on their distal parts. Deposits of this type are characteristic of P. magna. In contrast, specimens from Kermadec Trench have deposits with simple non-branched spines and arms which are not curved upwards on their distal parts (Fig. 5: F, G). This type of deposit is typical of P. discoveryi and therefore we consider these specimens to belong to $P$. discoveryi.

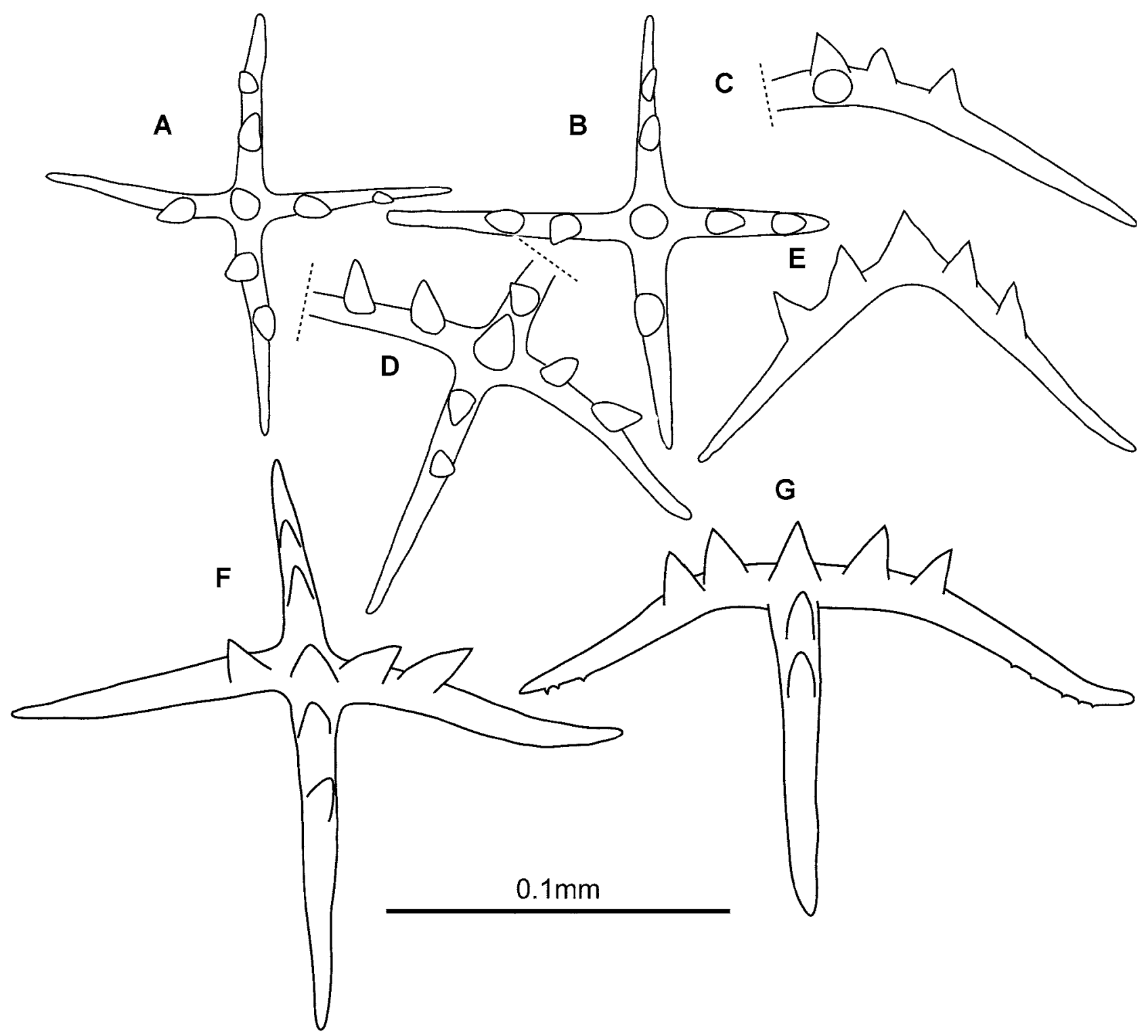

FIGURE 5. Psycheotrephes discoveryi sp. nov., dorsal deposits: A-E, holotype; F-G, Galathea, St. 663.

Relationships. Psycheotrephes discoveryi sp. nov. differs from other species in the genus in possessing only simple, non-branched spines on arms of primary crosses; and in the arms not displaying an upward inclination to their distal portions. $P$. discoveryi resembles $P$. magna in presence of three pairs of dorsal papillae and 18 tentacles.

Distribution. Southern Indian Ocean off Crozet Plateau, Kermadec Trench. Depths 4182-4410 m.

Genus Psychropotes Théel, 1882 
Euphronides scotiae Vaney, 1908: 418-419, Pls. I: 8-9, III: 39-40.

Psychropotes scotiae: Hansen, 1975: 111; Massin and Sibuet, 1983: 169-174, Pls. I-III.

Material examined: RRS Discovery, Cruise D300, St. 15773\#8, 7 specimens; St. 15773\#17, 4 specimens; St. 15773\#23, 20 specimens; St. 15773\#32, 3 specimens; St. 15775\#4, 15 specimens; St. 15775\#13, 1 specimen.

Diagnosis. Body elongate; anteriorly depressed, maximum width and height at base of unpaired dorsal appendage. Brim narrow. Tentacles 16. Dorsal papillae from 1-6 pairs located on anterior half of dorsum; posteriormost pair larger, located close to the middle of dorsum. Unpaired appendage short: $0.13-0.25$ of body length; placed on posterior third of dorsum and $\sim 0.25$ of body length from posterior end. Deposits in outer layer of body wall in form of small crosses with short central branched apophysis and downwardly angled spinous arms, up to $0.12 \mathrm{~mm}$ in length. Ventral deposits smaller, less spinous. Tri- and pentapartite deposits often present in dorsum and ventrum.

Description of material. Specimens varying in length from 1.8 to $25.2 \mathrm{~cm}$. Colour in alcohol: violet to dark violet. Body wall rough, covered with small warts, giving a verrucose appearance. Body elongated, rounded at both ends; posterior end narrower than anterior (Fig. 6: A, B). Anterior part of body depressed, increasing in width and height towards base of unpaired appendage. Brim narrow, visible only from ventral side. Tentacles 18 (11 in non-mature specimen). Midventral tube feet about 30 pairs, in double row. Dorsal papillae 3 pairs; 2 anterior pairs minute, behind gonopore; posteriormost pair larger and distal to other papillae, occupying mid-dorsal region. Unpaired appendage short: $0.13-0.17$ of body length, with broad base. Deposits (Fig. 6: C-J): small crosses with arms up to $0.12 \mathrm{~mm}$ in length on dorsum and up to $0.08 \mathrm{~mm}$ in length on ventrum. Tripartite deposits (Fig. 6: E, H) often present on dorsum and ventrum. Arms bent downward. Central apophyses short (up to $0.03 \mathrm{~mm}$ ), robust, branched. Arms possess large bifurcate spines; ventrally deposits are less spinous. Arms constricted distally or with clavate ends (especially on ventral deposits).

Remarks. Specimens examined were identified as Psychropotes scotiae based on presence of 16 tentacles, short unpaired appendage on posterior third of dorsum, deposits with short, robust central apophyses, spines and abundant tri- and pentapartite deposits.

P. scotiae was long known from a single Antarctic specimen. Another specimen was collected in the Cape Basin (Massin and Sibuet, 1983). Discovery of this species around Crozet has enabled clarification of the diagnosis. All specimens are similar in possessing 16 tentacles, numerous tripartite deposits and in the length and arrangement of the unpaired appendage. At the same time they differ in the number of dorsal papillae: the holotype bears one pair; a specimen from the Cape Basin has six pairs, and specimens from around the Crozet Plateau have three pairs. All known specimens share similarities in deposit morphology, tentacle number and size and arrangement of unpaired dorsal appendages; the number of papillae is a variable character. The number of dorsal papillae can be an important taxonomic character in the Elasipodida, but it varies in many species of the family Psychropotidae, such as Psychropotes depressa, P. verrucosa, Benthodytes typica, Psycheotrephes magna and others. Also, papillae can be easily lost during collection and/or preservation; it is possible that some of the papillae were lost from the holotype of P. scotiae.

Distribution. Antarctic (the Scotia Sea 62 $10^{\prime} \mathrm{S} 41^{\circ} 20^{\prime} \mathrm{W}, 3246 \mathrm{~m}$ ), South Atlantic (the Cape Basin $32^{\circ} 28^{\prime} \mathrm{S} 13^{\circ} 24^{\prime} \mathrm{E}, 3675 \mathrm{~m}$ ), South Indian Ocean (off Crozet Isles, 4182-4301 m). Depths 3246-4301 m. 

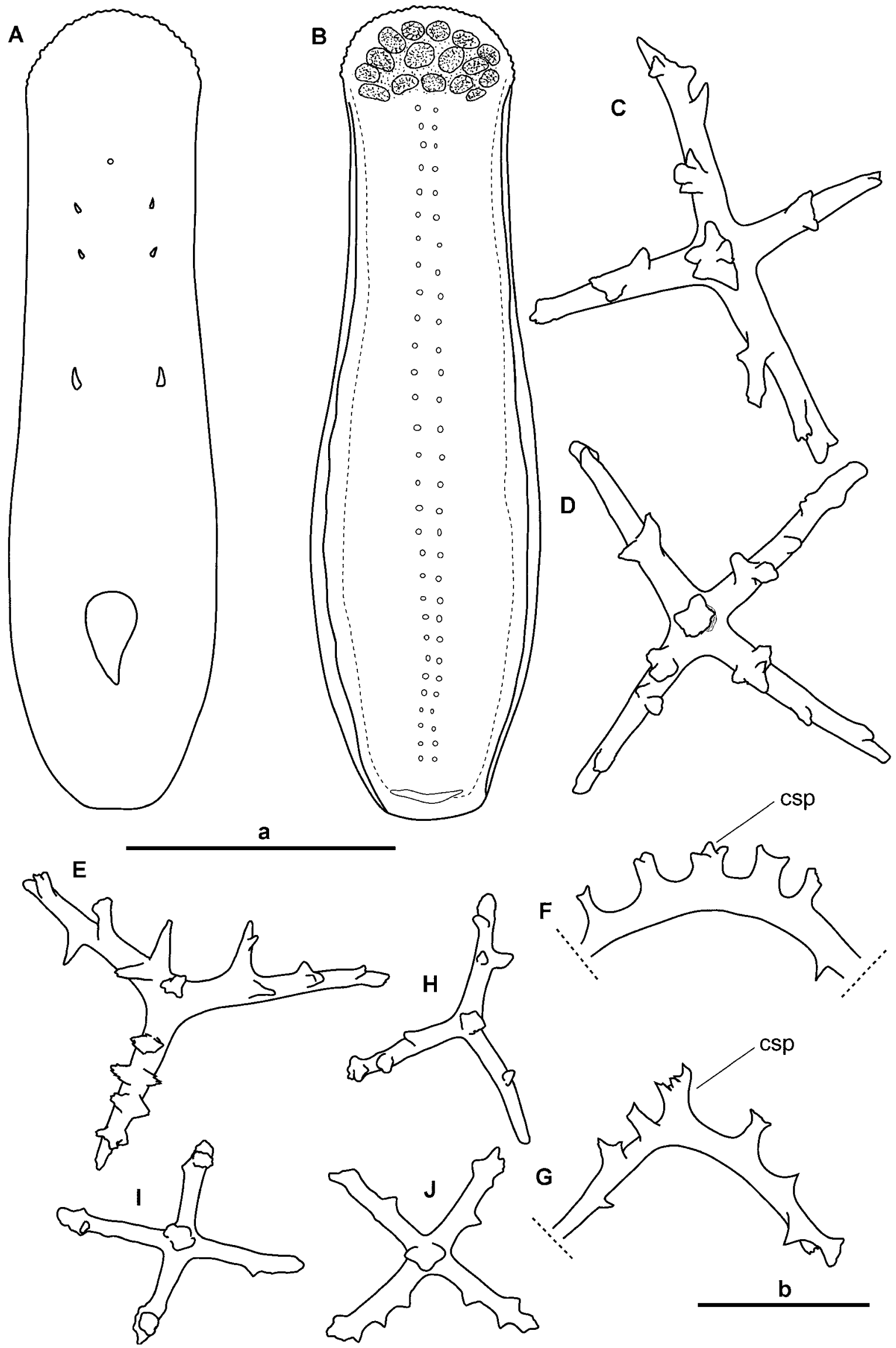

FIGURE 6. Psychropotes scotiae, St. 15773\#23. A, dorsal view; B, ventral view (scale a=5 cm); C-G, dorsal deposits; $\mathrm{H}-\mathrm{J}$, ventral deposits (scale $\mathrm{b}=0.1 \mathrm{~mm}$ ). 
Psychropotes longicauda Théel, 1882: 96-98, Pls. XXVII: 1, XXVIII, XXXV: 13-17, XXXVII: 10; Agatep 1967: 67, Pl. XI: 1-7; Hansen, 1975: 115-126, Figs. 49-54, Pls. VII: 4-6, XII: 7; Sibuet, 1977: 549-563; Massin et al., 1978: 253-259; Billett et al., 1985: 405, Figs. 1, 4; Walker et al., 1987: 277-282; Gebruk, 1993; Bluhm and Gebruk, 1999: 173-174, Fig. 3A; Wigham et al., 2003: 409-441; Gebruk 2008: 50, 51.

Psychropotes longicauda var. monstrosa Théel, 1882: 98-99, Pls. XXIX: 2, XXX, XXXIX: 1.

Psychropotes longicauda var. fusco-purpurea Théel, 1882: 99, Pls. XXIX: 1, XXXV: 11.

Psychropotes longicauda var. antarctica Vaney, 1908: 419-420.

Psychropotes buglossa E. Perrier, 1886: 283, Fig. 200; R. Perrier, 1902: 445-453, Fig. 7, Pls. XIII: 3-4, XX: 16-28; Hérouard, 1923: 105-108, Pls. I: 32, VI: 2.

Psychropotes raripes Ludwig, 1894: 48-51, Pl. V: 1-16; Ohshima 1915: 244; Clark 1920: 140-141, Pl. I: 1; Carney and Carey, 1976: 67-74.

Psychropotes dubiosa Ludwig, 1894: 52-53, Pl. II: 5-7.

Psychropotes grimaldii Hérouard, 1896: 167, Fig. 2; Hérouard, 1902: 25-27, Pl. III: 1-2.

Psychropotes fucata R. Perrier, 1896: 902; R. Perrier, 1902: 453-455, pl. XX: 29-30.

Psychropotes laticauda Vaney, 1908: 420-422, Pl. II: 14, 24.

Psychropotes brucei Vaney, 1908: 422-423, Pls. I: 13, II: 21-22, III: 41-42.

Euphronides dyscrita Clark, 1920: 139, Pl. II: 3.

Nectothuria translucida Belyaev and Vinogradov, 1969: 711-716, Figs. 1-4.

?Psychropodes longicaudata Carney and Carey, 1982: 597-607.

Material examined: RRS Discovery, Cruise D300, St. 15773\#8, 20 specimens; St. 15773\#17, 113 specimens; St. 5773\#23, 114 specimens; St. 15773\#32, 95 specimens; St. 15775\#4, 17 specimens; St. 15775\#13, 11 specimens.

Description of material. Body length varying from $1.8 \mathrm{~cm}$ to $34 \mathrm{~cm}$. Colour in alcohol: violet to dark violet. Body elongate, anterior part flattened and is the widest part of body, which decreases in width posteriorly, and increases in height towards unpaired dorsal appendage. Brim well developed on anterior and posterior ends of body, with maximum width around anterior part. Anterior brim consists of about 15 pairs of tube feet, and posterior brim of 7-8 pairs. Ventrolateral tube feet 17-19 pairs. Tentacles 18. Midventral tube feet large, conspicuous, sparsely distributed along middle of ventrum. Papillae minute, located on anterior half of dorsum. Distance between papillae increases towards posterior end of body. Unpaired dorsal appendage bifurcate, positioned close to posterior end of the body; varying in length from 0.2 of body length in large specimens to $0.25-0.29$ in small specimens, equal in width at the basis to body width. An unpaired appendage of 0.29 of body length was found only in 2 large specimens from St. 15773\#23. Deposits in form of crosses with short central apophysis up to $0.02 \mathrm{~mm}$, branched rarely smooth and downwardly inclined arms up to 0.15 mm long, contracted to ends. Arms with spines (up to four large spines per arm regularly distributed); proximal spines from half to about the same length with central apophysis; bipartite spines were occasionally observed; small spines at the end of arms. Few giant crosses were found on dorsum of 2 specimens: their arms reached $0.3 \mathrm{~mm}$ and central apophyses $0.08 \mathrm{~mm}$, proximal spines were smaller significantly than central apophyses, about 0.17 of it's length. Ventral deposits rods, tripartite or crosses, all with prominent spines.

Remarks. P. longicauda is a well known cosmopolitan species. It is found in all oceans except the Arctic from a wide depth range. Many authors have repeatedly pointed out the high variability of morphological characters in this species; and have even described new species and subspecies (see synonymy). In the last revision of the family Hansen (1975) synonymized nine species and three subspecies into "longicauda" because of intermediate stages between different morphological types. However, we suggest that $P$. longicauda includes more than one species and that the species needs to be revised (A.V. Gebruk, personal communication and our own data). Specimens found from around the Crozet Plateau resemble Psychropotes laticauda Vaney in deposit morphology, and this is probably a distinct species (slides of deposits of syntypes of this species made by Dr. Bent Hansen were studied at ZMUC). 
Distribution. Cosmopolitan. All oceans except the Arctic. Depths 2210-6134 m.

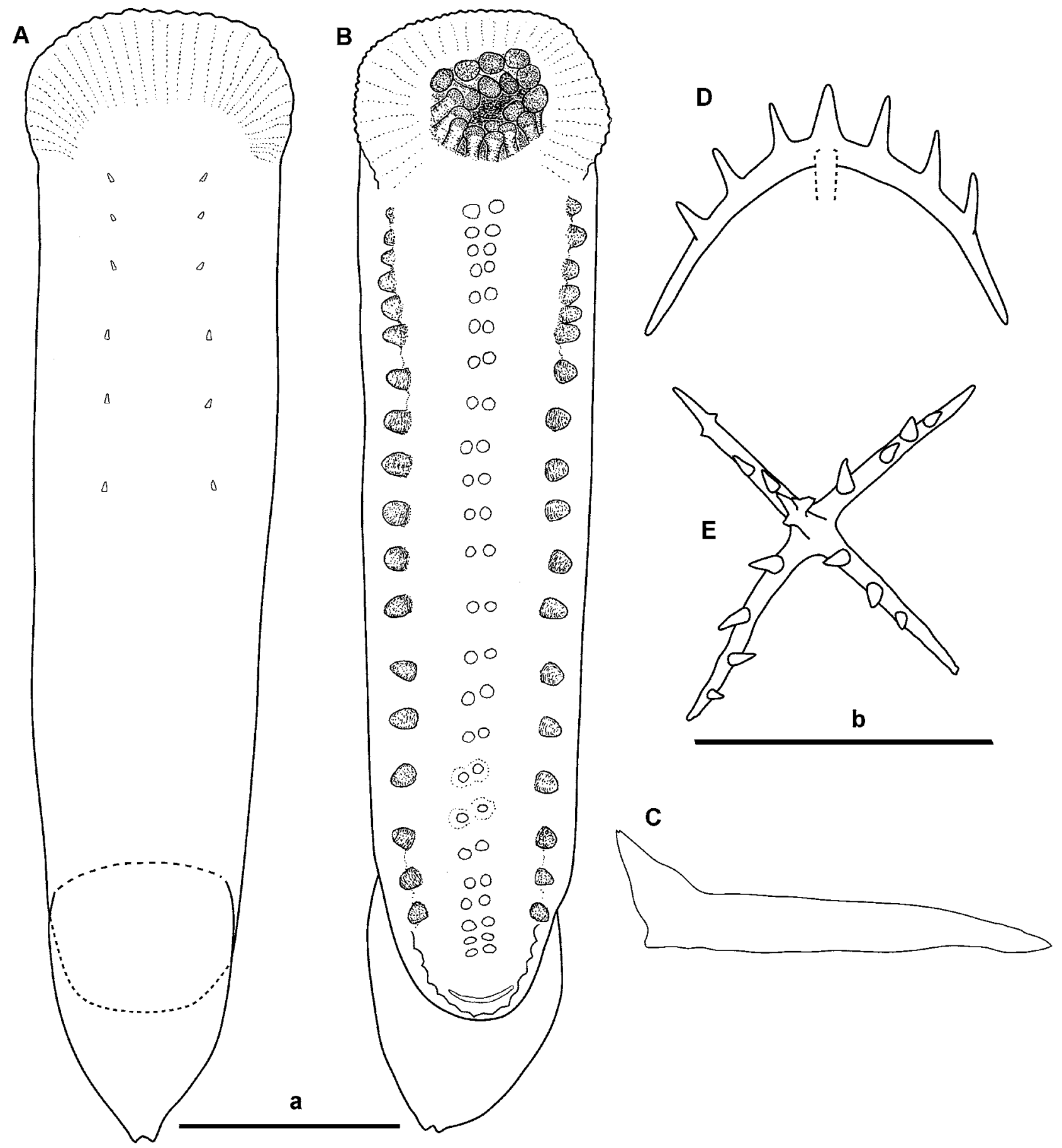

FIGURE 7. Psychropotes longicauda, St. 15773\#32. A, dorsal view; B, ventral view (scale a=5 cm); C, side view schematically; D, E, dorsal deposits (scale $\mathrm{b}=0.15 \mathrm{~mm}$ ).

Psychropotes xenochromata sp. nov. Rogacheva and Billett (Fig. 8-9)

Holotype: NHM 2009.1. Specimen $54 \mathrm{~mm}$ long and $19 \mathrm{~mm}$ of maximum width. RRS Discovery, Cruise D300, St. 15773\#32, 20 December 2005, 4540.45’S 56 33.70’E, 4267-4270 m, semi-balloon otter trawl. 

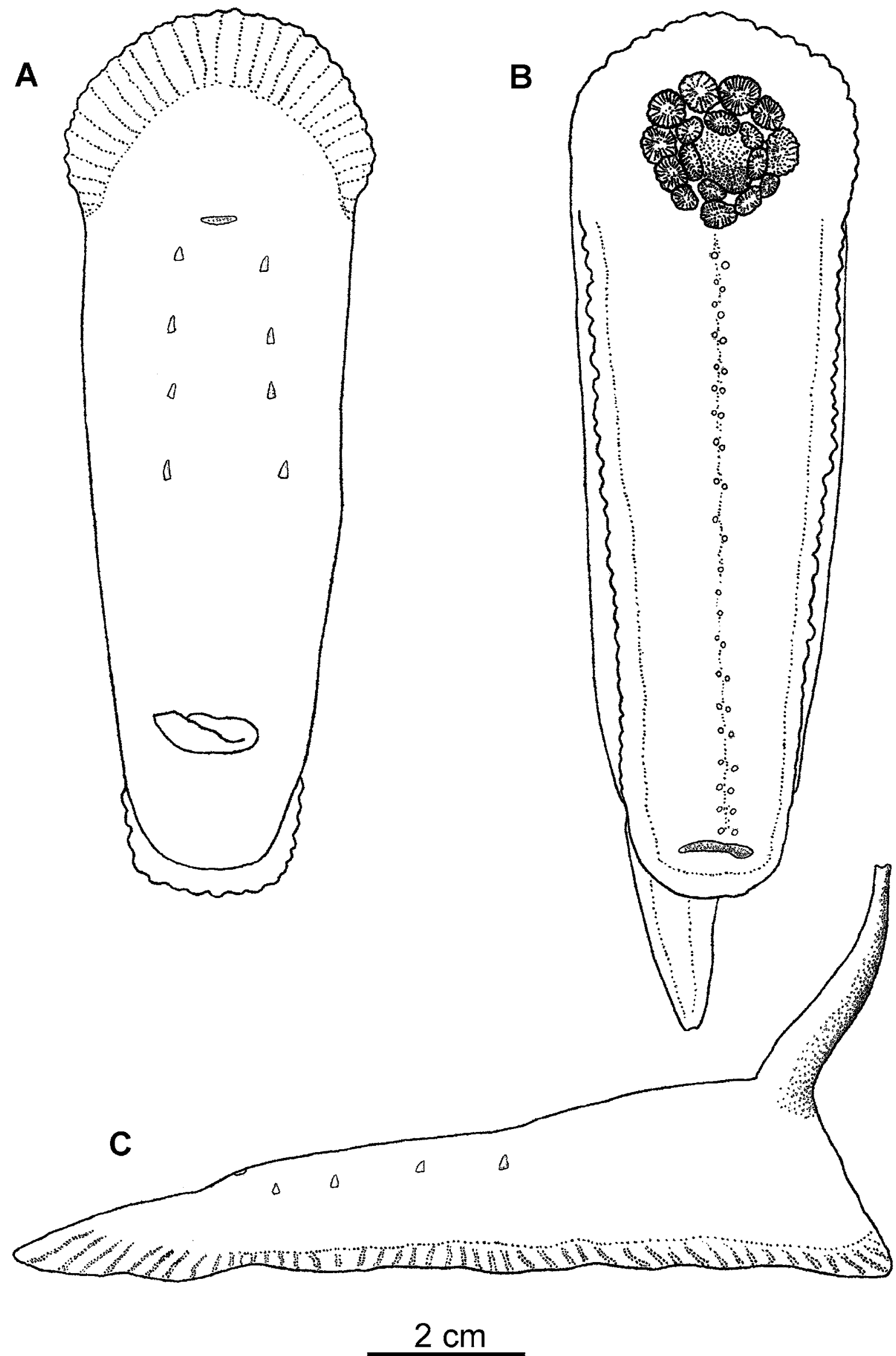

FIGURE 8. Psychropotes xenochromata sp. nov., holotype. A, dorsal view; B, ventral view, C, side view. 


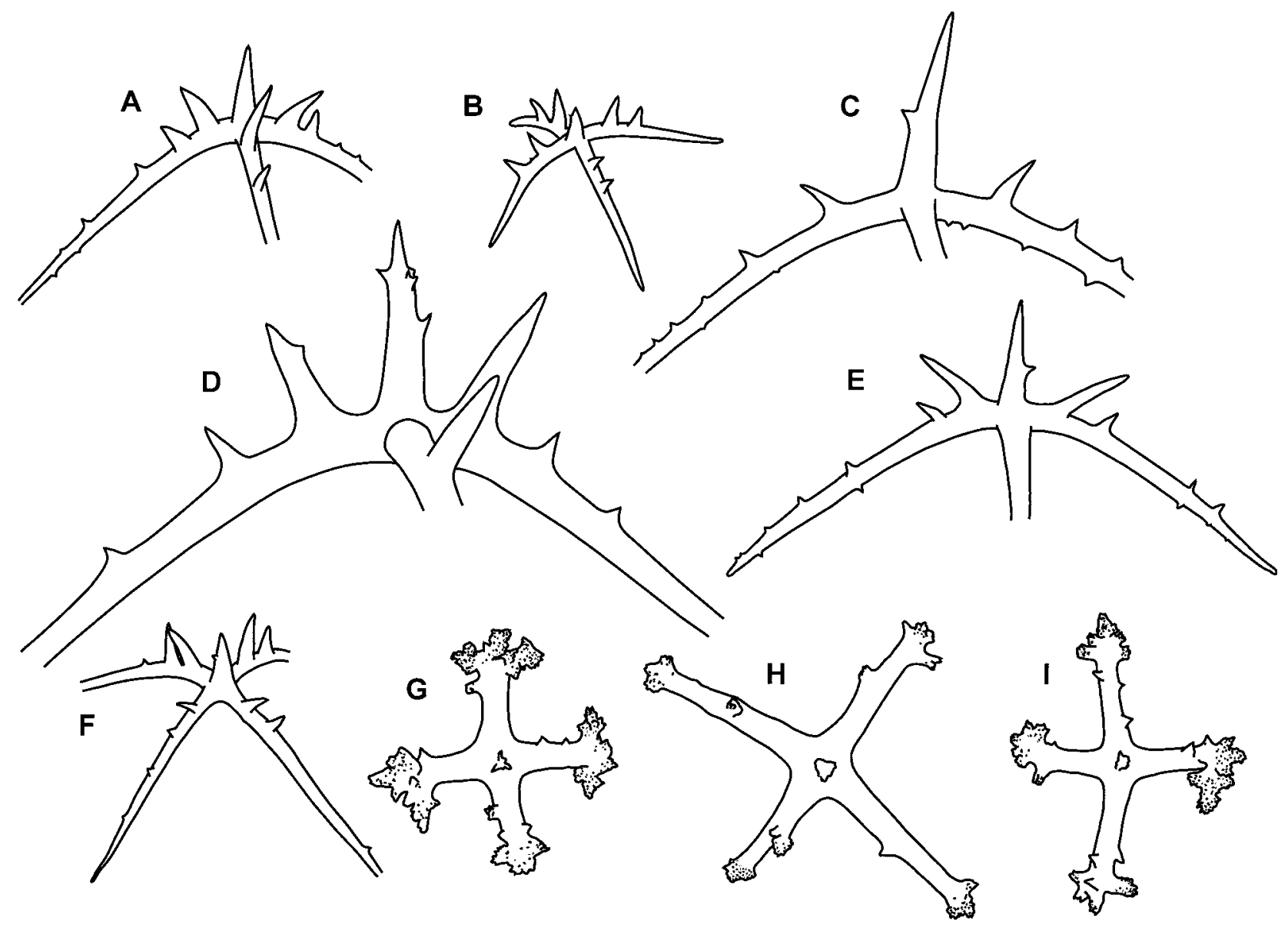

$0.1 \mathrm{~mm}$

FIGURE 9. Psychropotes xenochromata sp. nov. A-F, dorsal deposits; G-I, ventral deposits.

Paratypes: NHM 2009.2-4. 3 damaged specimens $55 \mathrm{~mm}, 60 \mathrm{~mm}$ and $65 \mathrm{~mm}$ long. RRS Discovery, Cruise D300, St. 15773\#17, 15 December 2005, 45 43.47'S, 56 36.66' E, 4301-4283 m, semi-balloon otter trawl; NHM, Cat. Nr NHM 2009.5. 1 damaged specimen $12 \mathrm{~cm}$ long. RRS Discovery, Cruise 300, St. 15775\#13 49 $01.15^{\prime} \mathrm{S}, 51^{\circ} 04.52^{\prime} \mathrm{E}, 4187-4191 \mathrm{~m}$, semi-balloon otter trawl.

Type locality: Southern Indian Ocean, to north-east and to south of the Crozet Isles, depth 4187-4301 m.

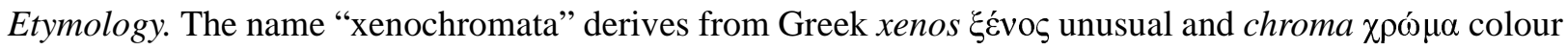
according to the uncommon colour of upper layer of skin.

Diagnosis. Body yellowish-green, elongate, dorsum slightly convex, ventrum flattened. Brim narrow. Tentacles 18. 4 pairs of minute papillae on anterior half of dorsum. Unpaired dorsal appendage bifurcate, placed 0.2 of body length from posterior end; varying in length from 0.2 to 0.5 of body length. Deposits on dorsum crosses, central apophysis with spines. Arms $0.1-0.3 \mathrm{~mm}$ long with 2 proximal spines larger than other spines on arms. Arms bent downwards. Ventral deposits with straight arms; ends of arms clavate with numerous spines; central apophysis short with numerous spines.

Description of the holotype. Specimen $54 \mathrm{~mm}$ long, $19 \mathrm{~mm}$ in maximum width in the anterior part, $16 \mathrm{~mm}$ width in the middle of body (Fig. 8: A, B, C). Colour in alcohol brownish-green. Brim narrow, with tips of tube feet. Tentacles 18. Midventral tube feet about 20 pairs sparsely distributed along the middle of ventrum. 4 pairs of papillae, posteriormost pair slightly larger, located close to the middle of dorsum. Unpaired dorsal appendage $17 \mathrm{~mm}$ long, $5 \mathrm{~mm}$ wide at the basis, with $2 \mathrm{knobs}$ at the end, located $9.5 \mathrm{~cm}$ in from posterior end; flattened, tapered to the end.

Description of material. Specimens have suffered extensive damage except the holotype. Body elongate, 
length from $5.5 \mathrm{~cm}$ to $12.0 \mathrm{~cm}$; maximum body width at anterior end. Colour of skin green, deeper layers light violet. Skin with dense layer of deposits; all specimens have lost some skin. Papillae and most of midventral tube feet lost except holotype. Tentacles 18. Unpaired dorsal appendage strongly damaged. Dorsal crosses (Fig. 9: A-F) with arms up to $0.4 \mathrm{~mm}$ in length and central apophysis up to $0.12 \mathrm{~mm}$ in length. Central apophysis with 1 or more small spines. Arms curved downwards, contracted to ends. 2 rarely 1, proximal spines larger than others; first proximal spine always larger than second and from 0.33 to 0.75 of the length of central apophysis. Small spines often occur on ventral side of arms (Fig. 9: A, C, E). Ventral crosses smaller than dorsal. Central apophysis small and branched. Arms up to $0.2 \mathrm{~mm}$ long, not curved, with few spines, some of them branched, with small spines. Arms with enlarged ends covered numerous spines.

Relationships. Psychropotes xenochromata sp. nov. differs by greenish colour of skin and dorsal crosses with 2 proximal spines larger than others. Green colour has never been reported in any species of the genus Psychropotes. Dorsal crosses in their morphology resemble those in Psychropotes longicauda s. 1.

Remarks. The green colour of skin in psychropotids has been recently reported for the genus Benthodytes, in B. gosarsi (Gebruk, 2008).

Distribution. Southern Indian Ocean off Crozet Plateau. Depth 4187-4301 m.

\section{Acknowledgements}

We would like to thank Andrew Cabrinovic (NHM), Sabine Stöhr (SMNH) and Claus Nielsen (ZMUC) for providing collections, warm welcome and great help. Special thanks are due to Andrey Gebruk for valuable critical comments and fruitful discussion and an anonymous reviewer for improving the manuscript. This work was supported by the CeDAMar exchange fellowship program for taxonomists, MAR-ECO, a field project under the Census of Marine Life programme and RFBI research grant 09-05-00868a.

\section{References}

Agatep, C.P. (1967) Some elasipodid holothurians of Antarctic and Subantarctis seas. Antarctic Research Series, 11, 49-71.

Belyaev, G.M. \& Vinogradov, M.E. (1969) A new pelagic holothurian (Elasipoda, Psychropotidae) from the abyssal of the Kurilo-Kamchatka Trench. Trudy Instituta Okeanologii Akademii Nauk SSSR, 48(5), 709-716 (in Russian, English summary).

Billett, D.S.M., Hansen, B. \& Huggett, Q.J. (1985) Pelagic Holothurioidea (Echinodermata) of the northeast Atlantic. Proceeding of the Fifth International Echinoderms Conference, Galway, Rotterdam: A.A. Balkema, pp. $399-411$.

Bluhm, H. \& Gebruk, A. (1999) Holothuroidea (Echinodermata) of the Peru Basin — ecological and taxonomic remarks based on underwater images. Marine Ecology, 20(2), 167-195.

Carney, R.S. \& Carey, J. (1976) Distribution pattern of holothurians of the Northeastern Pacific (Oregon, U.S.A.) continental shelf slope, and abyssal plain. Thalassia Jugoslavica, 12(1), 67-74.

Carney, R.S. \& Carey, J. (1982) Distribution and diversity of holothuroids (Echinodermata) on Cascadia Basin and Tufts Abyssal Plain. Deep-Sea Research, 29, 597-607.

Clark, H. L. (1913) Echinoderms from Lower California, with descriptions of new species. Bulletin of the American Museum of Natural History, 32, 185-236.

Clark, H.L. (1920) Holothurioidea. Memoirs of the Museum of Comparative Zoology. Report on the scientific results of the expedition to the tropical Pacific, in charge of Alexander Agassiz, by the U.S. fish commission steamer "Albatross", from August, 1899 to March, 1900, 39(4), 115-154.

Clark, H.L. (1923a) Echinoderms from Lower California (Supplimentary Report). Bulletin of the American Museum of Natural History, 48, 147-163.

Clark, H.L. (1923b) The Echinoderm Fauna of South Africa. Annals of the South African Museum, 13, $221-435$.

Gebruk, A.V. (1993) New data on elasipodid fauna of the South Atlantica and Antarctica. Trudy Instituta Okeanologii $R A N, 127,228-244$ (in Russian, English summary).

Gebruk, A.V. (2008) Holothurians (Holothuroidea, Echinodermata) of the northern Mid-Atlantic Ridge collected by the G.O. Sars MAR-ECO Expedition with description of four new species. Marine Biology Research, 5(1-2), 48-60.

Hansen, B. (1956) Holothurioidea from the depths exceeding 6000 meters. Galathea Report, 2, 33-54. 
Hansen, B. (1975) Systematics and biology of the deep-sea holothurians. Galathea Report, 13, 1-262.

Heding, S. (1940) Die Holothurien der Tiefsee-Expedition II. Aspidochirote und Elasipode Formen. Wissenschaftliche Ergebnisse der Deutschen Tiefsee-Expedition auf dem Dampfer "Valdivia" 1898-1899, 24, 317-395.

Hérouard, E. (1896) (Premier) note préliminaire sur les Holothuries provenant des dragegs du yacht "Princesse Alice". Bulletin de la Societe Zoologique de France, 21, 163-168.

Hérouard, E. (1902) Holothuries provenant des campagnes de la "Princesse-Alice" (1892-1897). Résultats des Campagnes Scientifiques accomplies sur son yacht par Albert I, Prince Souverain de Monaco, 21, 1-61.

Hérouard, E. (1923) Holothuries provenant des campagnes des yachts "Princesse-Alice" et "Hirondelle II" (1898-1915). Résultats des Campagnes Scientifiques du Prince de Monaco, 66, 1-163.

Hughes, J.A., Smith, T., Chaillan, F., Bett, B.J., Billett, D.S.M., Boorman, B., Fisher, E.H., Frenz, M. \& Wolff, G.A. (2007) Two abyssal sites in the Southern Ocean influenced by different organic matter inputs: Environmental characterization and preliminary observations on the benthic foraminifera. Deep-Sea Reseach II, 54 (18-20), 2275-2290.

Koehler, R. \& C. Vaney, C. (1905) Deep-sea holothuroidea collected by the Royal Indian Marine Survey Ship Investigator. Calcutta, $126 \mathrm{pp}$.

Ludwig, H. (1894) The Holothurioidea. Reports on an exploration off the west coasts of Mexico, Central and South America, and off the Galapagos Islands, in charge of Alexander Agassiz, by the U.S. Fish Comission Streamer "Albatross», during 1891. Memoirs of the Museum of Comparative Zoology, Cambridge, 17, 1-183.

Marenzeller, E. von (1893) Contribution à l'étude des Holothuries de l'Atlantique Nord. Résultats des Campagnes Scientifiques accomplies sur son yacht par Albert I Prince souverain de Monaco, 6, 1-22.

Massin, C., Jangoux, M. \& Sibuet, M. (1978) Description d'Ixoreis psychropotae nov. gen., nov. sp., coccidie parasite du tube digestif de l'holothurie abyssale Psychropotes longicauda Théel. Protistologica, 14(3), 253-259.

Massin, C. \& Sibuet, M. (1983) Decouverte dans le bassin profond du Cap de l'espece antarctique Psychropotes scotiae (Vaney, 1908) (Echinodermata Holothuroidea). Bulletin du Museum National d'Histoire Naturelle Section A Zoologie Biologie et Ecologie Animales, 5(1), 169-174.

Ohshima, H. (1915) Report on the holothurians collected by the United States Steamer "Albatross" in the northwestern Pacific during the summer of 1906. Proceedengs of the United States National Museum, 48, 213-291.

Pawson, D.L. (1982) Deep-sea echinoderms in the Tongue of the Ocean, Bahama islands: A survey, using the research submersible Alvin. Australian Museum Memoirs, (16), 129-145.

Pawson, D.L. (1985) Psychropotes hyalinus, new species, a swimming elasipod sea cucumber (Echinodermata: Holothuroidea) from the North Central Pacific Ocean. Proceedings of the Biological Society of Washington, 98(2), $523-525$.

Perrier, E. (1886) Les explorations sous-marines. Paris, $352 \mathrm{pp}$.

Perrier, R. (1896) Sur les Élasipodes recueillis par le "Travailleur" et le "Talisman". Comptes Rendus Hebdomadaires des Séances del'Academie des Sciences Paris, 123, 900-903.

Perrier, R. (1902) Holothuries. Expéditions scientifiques Travailleur et du Talisman, 7, pp. 273-554.

Sluiter, C.P. (1901a) Neue Holothurien aus der Tief-See des Indischen Archipels gesammelt durch die SibogaExpedition. Tijdschrift der Nederlandsche Dierkundige Vereeniging 2, 7, 1-28.

Sluiter, C.P. (1901b) Die Holothurien der Siboga-Expedition. Siboga-Expeditie, 44, 1-142.

Théel, H. (1879) Preliminary report on the Holothuridae of the Exploring voyage of H.M.S. "Challenger".I. Bihang till Kongliga Svenska Vetenskaps-akademiens Handlingar, 5(19), 1-20.

Théel, H. (1882) Report on Holothurioidea. Pt. I. Report of the Scientific Results of the Voyage of H.M.S. Challenger. Zoology, 4(13), 1-176.

Théel, H. (1886) Report on Holothurioidea. Reports on the results of dredging, under the Supervision of Alexander Agassiz, in the Gulf of Mexico (1877-78), in the Caribbean Sea (1879-80), and along the Eastern Coast of the United States during the Summer of 1880, by the U.S. Coast Survey Steamer "Blake". Bulletin of the Museum of Comparative Zoology, 13, 1-21.

Vaney, C. (1908) LLes Holothuries de l'Expédition Antarctique Nationale Écossaise. Transactions of the Royal Society of Edinburgh, 46, Part II(18), 405-441.

Walker, M., Tyler, P.A. \& Billett, D.S.M. (1987) Organic and calorific content of the body tissues of deep-sea elasipodid holothurians in the northeast Atlantic Ocean. Marine Biology, 96(2), 277-282.

Wigham, B.D., Hudson, I.R., Billett, D.S.M. \& Wolff, G.A. (2003) Is long-term change in the abyssal Northeast Atlantic driven by qualitative changes in export flux? Evidence from selective feeding in deep-sea holothurians. Progress in Oceanography, 59(4), 409-441.

Wolff, G.A. (2006) Initial Cruise Report. D300 Benthic CROZET. 1st December 2005-14th January 2006,139 pp. Available from: http://www.bodc.ac.uk/data/information_and_inventories/cruise_inventory/report/d300.pdf (Date of access 20.10.2007). 